\title{
Sensibility Test of Candida species against Nystatin, Ketoconazole, and Fluconazole on Oral Candidiasis with HIV/AIDS using Disc Diffusion Method
}

\author{
Cut Shelma Maharani, Rahmadewi, Afif Nurul Hidayati, Dwi Murtiastutik \\ Department of Dermatology and Venereology, Faculty of Medicine, Universitas Airlangga/Dr. \\ Soetomo General Academic Teaching Hospital, Surabaya, Indonesia
}

\begin{abstract}
Background: Oral candidiasis is one of the most common infections in Human Immunodeficiency Virus/Acquired Immuno Deficiency Syndrome (HIV/AIDS) patients. Some studies have reported an increased number of resistances of Candida $s p$. against several antifungal therapies. Purpose: To evaluate the pattern of Candida sp. causing oral candidiasis and the pattern of resistance among the Candida sp. against nystatin, ketoconazole, and fluconazole in oral candidiasis patients with HIV/AIDS infection. Methods: This was a descriptive observational study conducted at the Infectious Disease Intermediate Care Unit (UPIPI) Dr. Soetomo General Academic Teaching Hospital. Candida sp. was identified using conventional methods, while the sensibility test was done by using disc diffusion methods. Result: There were 26 subjects with 50 isolates of Candida $s p$. that had been cultured successfully. Non-albicans Candida $s p$. was the most common species, which was observed in 28 subjects $(56 \%)$. The results of the sensibility test on Candida sp. against nystatin, ketoconazole, and fluconazole were $0(0 \%)$, 3(6\%), dan 23(46\%) respectively. Conclusion: The increased resistance among Candida sp. against antifungal drugs, especially fluconazole, could raise awareness in drug prescription, especially for HIV/AIDS patients.
\end{abstract}

Keywords: sensibility test, Candida $s p$., antifungals, oral candidiasis.

Correspondence: Dwi Murtiastutik, Department of Dermatology and Venereology, Faculty of Medicine, Universitas Airlangga/Dr. Soetomo General Academic Teaching Hospital, Jl. Mayjen Prof. Dr. Moestopo No. 6-8, 60131, Surabaya, Indonesia. Telephone: +6231-5501609, e-mail: dwimurtiastutik@yahoo.co.id.

\section{BACKGROUND}

It has been four decades since Acquired Immune Deficiency Syndrome (AIDS) was first discovered, and Human Immunodeficiency Virus (HIV) transmission still has a major impact on developing countries and become a global crisis. ${ }^{1}$ Directorate General of Disease Prevention and Control of the Indonesian Ministry of Health (Ditjen PP \& PL Kementerian Kesehatan) in 2016 reported 7,491 new cases of HIV/AIDS and a total of 86,780 cases from 1987 to $2016 .^{2}$

People infected with HIV have a weakened immune system; therefore, they become vulnerable to opportunistic infections. Fungal opportunistic infections in HIV patients are one of the causes of morbidity and decreased quality of life. Oral Candidiasis (OC) has been reported as the most common opportunistic fungal infection in HIV patients. ${ }^{3}$ Genus Candida are the most commonly found fungi in the oral cavity. The most commonly reported etiology of OC is Candida albicans. There has been an etiological change of non-albicans Candida. ${ }^{3,4}$ It has been reported that almost all people infected with HIV have Candida colonization up to $90-95 \%$ and the fungi developed into clinical lesions, especially in the oral cavity. ${ }^{4}$ A retrospective study in 2013 at Dr. Soetomo General Academic Teaching Hospital
Surabaya showed that of $301 \mathrm{HIV} /$ AIDS patients at Infectious Disease Intermediate Care Unit (UPIPI) with manifestations on the skin, there were 244 (81.1\%) patients diagnosed with OC. ${ }^{5}$

OC patients with HIV often have an extended duration of illness, recurring illness, and more severe clinical symptoms. ${ }^{6}$ Further examination to establish OC diagnosis is a direct mycological examination with potassium hydroxide $(\mathrm{KOH})$ followed by planting specimens in CHROMagar ${ }^{\mathrm{TM}}$ media to grow the Candida colonies. ${ }^{7}$ Identification of Candida species now can be made through several methods, namely conventional, automatic, and molecular. Conventional Candida sp. identification includes CHROMagar ${ }^{\mathrm{TM}}$ Candida, cornmeal agar-Tween 80, and carbohydrate tests. Accurate results can be achieved by combining the three conventional methods to complement the results of each method. ${ }^{8}$ Research on comparison of the three Candida identification methods by Kaur in 2016 in India showed that a combination of the three conventional methods had higher results (99.4\%) compared to Vitek 2 (90.1\%). ${ }^{9}$

The management of OC shall consider many factors. However, in some cases, $\mathrm{OC}$ is treated empirically with antifungal. ${ }^{6}$ Referring to the clinical practice guidelines of the Dermatology and 
Venereology Department Dr. Soetomo General Academic Teaching Hospital Surabaya in 2014, the drugs that are often prescribed for OC therapy are nystatin, ketoconazole, and fluconazole. ${ }^{10}$

Since its discovery in 1990, the incidence of resistance to antifungal agents in patients with HIV/AIDS has been reported to increase, especially in azole antifungal agents. Studies from various places show the resistance of Candida sp. to fluconazole ranges between $6 \%-36 \%$, while the azole group is increasingly being used due to numerous medical indications. Increased use of antifungal agents to treat fungal infections in immunocompromised patients is said to be one of the factors causing the emergence of drug resistance to Candida isolates. ${ }^{4}$ Another factor is the improper doses in terms of duration, which will trigger secondary resistance. The etiology of OC that was caused by non-albicans Candida group is also shown to correlate with azole antifungal resistance and recurrent and refractory candidiasis infections. ${ }^{11}$ Some strains of non-albicans Candida are intrinsically resistant to azole and polyene groups without prior drug exposure, which is the cause of primary resistance. $^{4}$

Research on antifungal agent resistance rates in OC patients with HIV/AIDS in Indonesia conducted in Malang by Reza in 2014, using Vitek 2 as a resistance test method, found that $8 \%$ of Candida isolates were resistant to fluconazole and caused by Candida krusei. ${ }^{12}$ A 2015 Jakarta study, comparing the Vitek 2 method of resistance testing with the diffusion disc method, showed that 9 of 137 Candida isolates were caused by Candida krusei, and this species was 100\% resistant to fluconazole. ${ }^{13}$ A study by Moges on the resistance rates of several antifungals with diffusion disc testing in HIV/AIDS patients with OC in Ethiopia 2013 - 2014 showed that of all Candida isolates found $12.3 \%$ resistant to fluconazole, $8.4 \%$ to ketoconazole, and $1.3 \%$ to nystatin. ${ }^{4}$

The examination of Candida $s p$. resistance to antifungal drugs can be done with several methods. The conventional method consisted of a dilution method and an agar diffusion disc method. Both examinations are more affordable compared to methods with commercial tools such as Vitek 2, Etest, and SensitreYeastOne. ${ }^{14}$

In vitro examinations of species identification culture and resistance patterns in Candida sp. are not routinely done in Indonesia, so there are only a few recent data on this, especially in Surabaya. ${ }^{15}$ This study aimed to evaluate the patterns of Candida sp. that cause OC in HIV/AIDS patients and Candida sp. resistance patterns against antifungal drugs commonly used in the treatment of OC.

\section{METHODS}

This was a descriptive observational study to evaluate the patterns of Candida sp. that cause OC and Candida sp. resistance patterns against antifungal nystatin, ketoconazole, and fluconazole at the Infectious Disease Intermediate Care Unit (UPIPI) Dr. Soetomo General Academic Teaching Hospital Surabaya. The study was conducted from May 2018 to September 2018. The sample size, which was calculated based on a categorical descriptive formula, was 26 patients. The samples of this study were patients with a confirmed clinical diagnosis of OC from history taking, clinical manifestations, and direct microscopic examination with $\mathrm{KOH}$. The inclusion criteria was that the patient was willing to participate in the study, while the exclusion criteria was that the patient was taking antifungal drugs in the last 2 weeks. Subjects who had fulfilled those criteria would have their lesions in the oral cavity scraped, and then the specimen would be implanted in CHROMagar ${ }^{\mathrm{TM}}$ media until the colonies grew. Subsequent tests were Cornmeal agar-Tween 80 and carbohydrate tests for species identification. The identified Candida sp. were then tested for resistance by the disc diffusion method on Mueller Hinton agar with $2 \%$ glucose and methylene blue. Candida sp. isolates were implanted in the agar, then paper disc containing the potential of nystatin, ketoconazole, and fluconazole was placed on it. Observation in $24-48$ hours was carried out until a barrier zone appears around the paper disc. The interpretation of inhibition zone diameter readings was according to Rosco Diagnostica Company. ${ }^{4}$

\section{RESULT}

As many as 26 patients in Infectious Disease Intermediate Care Unit (UPIPI) Dr. Soetomo General Academic Teaching Hospital that fulfill inclusion criteria were involved in this study. Sampling was done by consecutive sampling method.

Demographic distribution in this study revealed that 20 subjects $(76.9 \%)$ were males, and 6 $(23.1 \%)$ were females. The age group varied between 17 - 25 years old to 56 - 65 years old. The age classification based on the World Health Organization (WHO) criteria. The largest age group was $36-45$ years old with 7 subjects (26.9\%), and the smallest age group was $18-25$ years old with 3 subjects (11.5\%). None of the subjects was categorized as an elderly ( $>$ 66 years). The most common formal education level was the high school with 11 subjects $(42.3 \%)$, and the highest $(34.6 \%)$ occupation group of the research subjects was unemployed (Table 1). The twenty-six patients showed varies chief complaints of OC clinical features, and one patient might have more than one 
chief complaint. The most common complaint was white patches in the oral cavity, as observed in 25 (96.2\%) subjects. Furthermore, 5 (19.2\%) patients also complained of odynophagia or a burning sensation in the throat. All OC patients in this study, $100 \%$ had lesion that located on the tongue, and all subjects also had mixed lesion sites (mucosa/palate/corners of the lips). There were $11(42.3 \%)$ patients who had a history of OC before, while 15 (57.7\%) patients had OC for the first time. There were 5 patients $(19.2 \%)$ prescribed with systemic drugs, and 10 patients (38.5\%) prescribed with topical antifungal drugs (Table 2).

Table 1. Demographic data of research subjects

\begin{tabular}{|c|c|c|c|c|}
\hline \multirow{2}{*}{ No } & \multicolumn{2}{|r|}{ Basic Data } & \multirow[t]{2}{*}{$\mathrm{N}$} & \multirow[t]{2}{*}{$\%$} \\
\hline & Categories & Groups & & \\
\hline \multirow{2}{*}{1} & \multirow{2}{*}{ Sex } & Male & 20 & $76.9 \%$ \\
\hline & & Female & 6 & $23.1 \%$ \\
\hline \multirow{6}{*}{2} & \multirow{6}{*}{ Age } & Late Teen $(18-25$ years old $)$ & 3 & $11.5 \%$ \\
\hline & & Early Adulthood ( $26-35$ years old $)$ & 6 & $23.1 \%$ \\
\hline & & Late Adulthood ( $36-45$ years old) & 7 & $26.9 \%$ \\
\hline & & Early Middle Age (46 - 55 years old) & 6 & $23.1 \%$ \\
\hline & & Late Middle Age ( $56-65$ years old $)$ & 4 & $15.4 \%$ \\
\hline & & Elderly $(>66$ years old) & 0 & 0 \\
\hline \multirow{4}{*}{3} & \multirow{4}{*}{$\begin{array}{c}\text { Formal Education } \\
\text { Level }\end{array}$} & No History of Formal Education & 4 & $15.4 \%$ \\
\hline & & Primary/Middle School Graduate & 8 & $30.8 \%$ \\
\hline & & High School Graduate & 11 & $42.3 \%$ \\
\hline & & Bachelor Degree & 3 & $11.5 \%$ \\
\hline \multirow{9}{*}{4} & \multirow{9}{*}{ Occupation } & Unemployed & 9 & $34.6 \%$ \\
\hline & & Housewife & 5 & $19.2 \%$ \\
\hline & & Civil Worker & 2 & $11.5 \%$ \\
\hline & & Private Employee & 5 & $19.2 \%$ \\
\hline & & Driver & 2 & $7.7 \%$ \\
\hline & & Student & 1 & $3,8 \%$ \\
\hline & & Sex Worker: & & \\
\hline & & - Direct (Transwoman) & 1 & $3.8 \%$ \\
\hline & & - Indirect (Hairdresser) & 1 & $3.8 \%$ \\
\hline
\end{tabular}

Table 2. Distribution of research subjects based on clinical features of oral candidiasis

\begin{tabular}{|c|c|c|c|c|}
\hline \multirow{2}{*}{ No } & \multicolumn{2}{|r|}{ Clinical Features } & \multirow[t]{2}{*}{$\mathrm{N}$} & \multirow[t]{2}{*}{$\%$} \\
\hline & Categories & Groups & & \\
\hline \multirow{4}{*}{1} & \multirow{4}{*}{ Chief complaints* } & White patches on the oral cavity & 25 & 96.2 \\
\hline & & Red patches on the oral cavity & 1 & 3.8 \\
\hline & & Spots and sores on the corners of the lips & 1 & 3.8 \\
\hline & & $\begin{array}{l}\text { Spotting or sores accompanied by odynophagia or a } \\
\text { burning sensation in the throat }\end{array}$ & 5 & 19.2 \\
\hline \multirow{3}{*}{2} & \multirow{3}{*}{ Locations* } & Mucosa & 1 & 3.8 \\
\hline & & Tounge & 26 & 100 \\
\hline & & Corners of the Lips & 1 & 3.8 \\
\hline \multirow{2}{*}{3} & \multirow{2}{*}{ Frequency } & Recurring & 10 & 38.5 \\
\hline & & Once & 16 & 61.5 \\
\hline \multirow{6}{*}{4} & \multirow{6}{*}{ History of treatment* } & Systemic Antifungal & & \\
\hline & & Yes & 5 & 19.2 \\
\hline & & No & 21 & 80.8 \\
\hline & & Topical Antifungal & & \\
\hline & & Yes & 10 & 38.5 \\
\hline & & No & 16 & 61.5 \\
\hline
\end{tabular}

* Patients may have $>1$ chief complaints, locations, and history of treatments 
Sixteen people $(61.5 \%)$ with HIV/AIDS were infected from heterosexual intercourse and six people $(26.9 \%)$ from homosexual intercourse. Subject might get infected from more than one HIV transmissions. Most of the subjects were in clinical stage III and IV HIV, which were 14 people $(53.8 \%)$ and 11 people $(42.3 \%)$, respectively. There were 21 study subjects $(80.8 \%)$ with a history of having antiretroviral (ARV) therapy (Table 3).

The most common diagnosis of OC was pseudomembrane candidiasis found in 21 patients $(80.8 \%)$, followed by plaque hyperplastic type, atrophic type, and cheilitis types in 7 (26.9\%), 1 $(3.8 \%)$, and $1(3.8 \%)$ patient respectively. The systemic treatment plan of OC cases using fluconazole was found in 7 cases $(26.9 \%)$, while topical oral nystatin was found in 19 cases $(73.1 \%$ ) (Table 4).

The identification of Candida sp. revealed that 28 isolates (56\%) were non-albicans Candida sp., which was more significant than the 22 Candida albicans isolates (44\%). The number of non-albicans Candida sp. were Candida tropicalis, Candida glabrata, and Candida krusei, as many as 9 (18\%), 8 (16\%), and 7 $(14 \%)$ isolates respectively. This study also found rare isolates of Candida, namely Candida parapsilosis, Candida dubliniensis, and Candida guilermondii (Table 5).

Fifty species of isolates that were tested for resistance, reveal most Candida $s p$. species were still sensitive to ketoconazole and nystatin, respectively 42 (84\%) isolates and $49(98 \%)$ isolates. On the other hand, only 27 isolates $(54 \%)$ were sensitive to fluconazole. Candida albicans species were still sensitive to the three antifungal drugs ketoconazole, nystatin, and fluconazole, respectively 22 (100\%), 21 $(95.5 \%)$, and $16(72.7 \%)$. Another case with nonalbicans Candida sp., although most were sensitive to the ketoconazole and nystatin, which were 20 (71.4\%) and $28(100 \%)$ isolates, only 11 isolates $(39.3 \%)$ were sensitive to fluconazole. The overall pattern of antifungal resistance in Candida $s p$. isolates was varying. The number of isolates resistant to ketoconazole, nystatin, and fluconazole were 3 $(10.7 \%), 0(0 \%)$, and $23(46 \%)$. The number of Candida isolates resistant to fluconazole was mostly caused by non-albicans Candida species was 17 $(60.7 \%)$ (Table 6).

Table 3. Characteristics of research subjects based on HIV status

\begin{tabular}{|c|c|c|c|c|}
\hline \multirow{2}{*}{ No } & \multicolumn{2}{|c|}{ HIV Status } & \multirow[t]{2}{*}{$\mathrm{N}$} & \multirow[t]{2}{*}{$\%$} \\
\hline & Categories & Groups & & \\
\hline \multirow{5}{*}{1} & \multirow{5}{*}{ HIV possibility mode of transmission* } & Homosexual & 7 & 26.9 \\
\hline & & Heterosexual & 16 & 61.5 \\
\hline & & Bisexual & 1 & 3.8 \\
\hline & & Injected Narcotics/Tatto & 5 & 19.2 \\
\hline & & Transfusion & 1 & 3.8 \\
\hline \multirow{3}{*}{2} & \multirow{3}{*}{ Duration of HIV } & $<1$ year & 12 & 46.2 \\
\hline & & $1-3$ years & 9 & 34.6 \\
\hline & & $>3$ years & 5 & 19.2 \\
\hline \multirow{4}{*}{3} & \multirow{4}{*}{ HIV clinical stages } & Stage I & 0 & 0 \\
\hline & & Stage II & 1 & 3.8 \\
\hline & & Stage III & 14 & 53.8 \\
\hline & & Stage IV & 11 & 42.3 \\
\hline \multirow{3}{*}{4} & \multirow{3}{*}{ Absolute CD4 count } & $>500$ cells $/ \mu \mathrm{L}$ & 0 & 0 \\
\hline & & $200-500$ cells $/ \mu \mathrm{L}$ & 10 & 38.5 \\
\hline & & $<200$ cells $/ \mu \mathrm{L}$ & 16 & 61.5 \\
\hline \multirow{2}{*}{5} & \multirow{2}{*}{ History of antiretroviral therapy } & Yes & 21 & 80.8 \\
\hline & & No & 5 & 19.2 \\
\hline
\end{tabular}

* Patient can be infected by $>1$ HIV mode of transmission

$\mathrm{HIV}=$ human immunodeficiency virus 


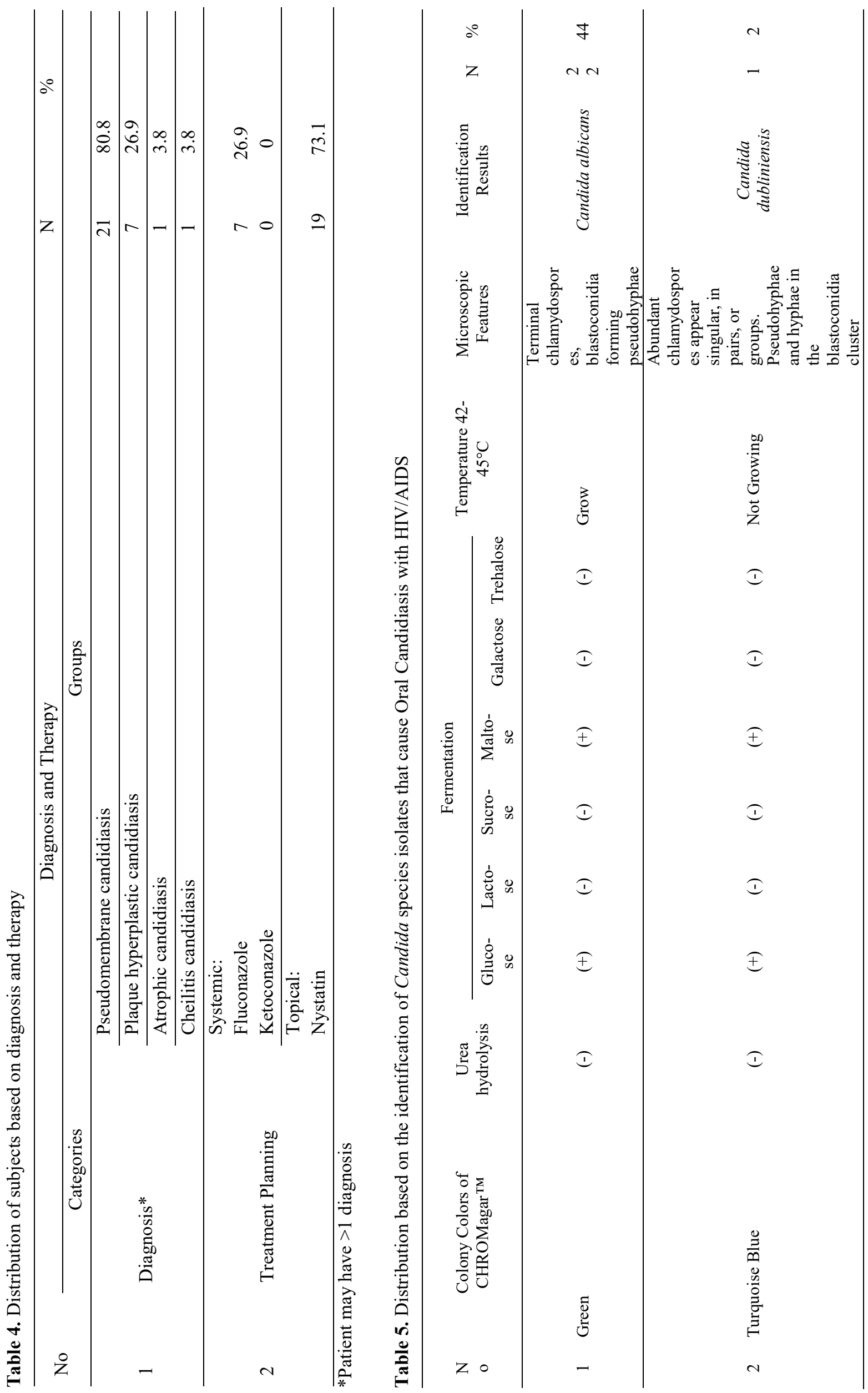




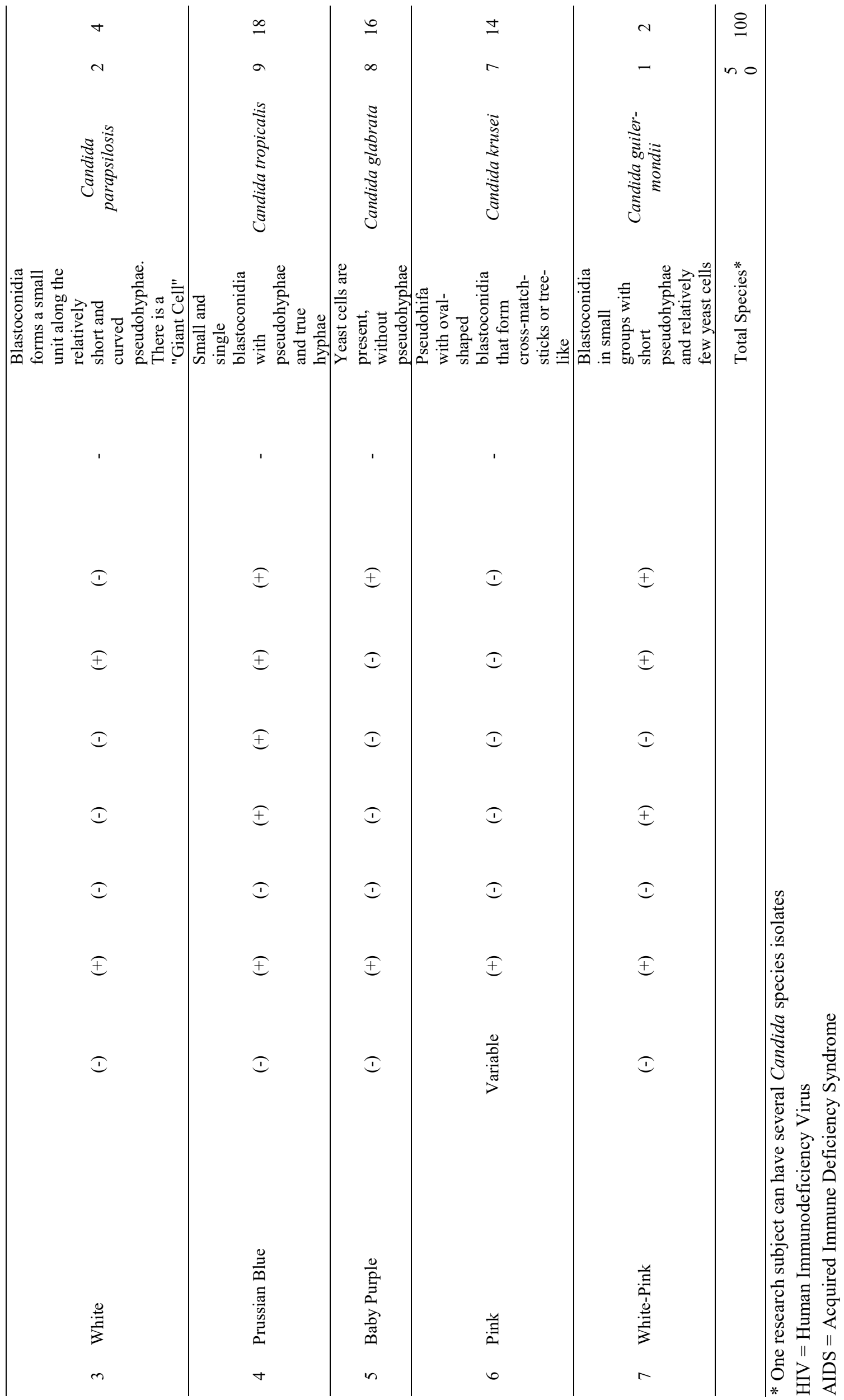




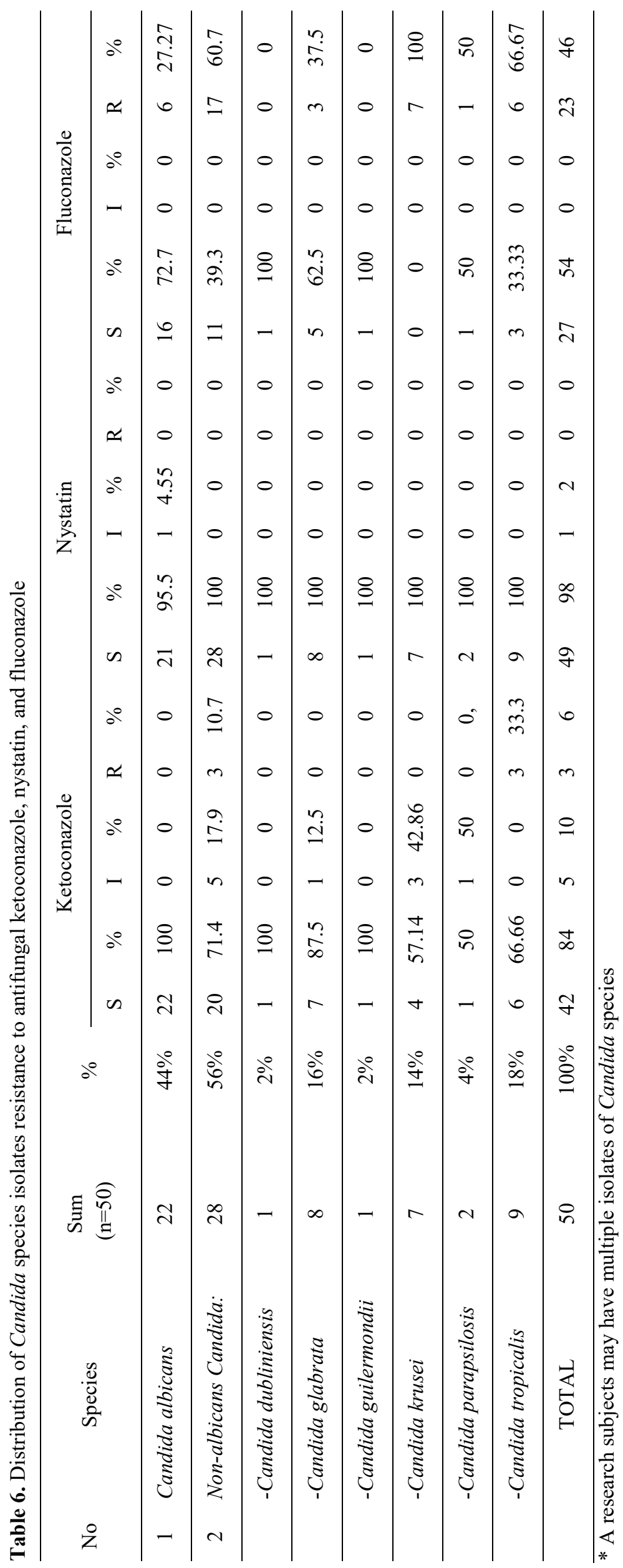




\section{DISCUSSION}

The distribution of research subjects were 20 males $(76.9 \%)$ and $6(23.1 \%)$ females. OC is not similar to vulvovaginal candidiasis, which is influenced by hormonal factors. Thus, in general, no difference in terms of sex was observed. ${ }^{12}$ The largest age group in the study was $36-45$ old years with 7 (26.9\%) patients, followed by $26-35$ and $46-55$ years old, with each $6(23.1 \%)$ patients. These findings suggested that adults who are in the productive age and sexually active are more likely to engage in unprotected sexual behavior at risk for HIV transmission. ${ }^{12}$ The distribution of the highest formal education levels was 4 people $(15.4 \%)$ who never attended school, and 8 people $(30.8 \%)$ were primary/middle school graduates. HIV/AIDS patients with low educational background have low oral health knowledge and prone to oral diseases. ${ }^{12}$ An educated person has a better understanding of information, especially health information, about the prevention of opportunistic diseases such as OC in HIV/AIDS. ${ }^{16}$ The distribution of occupational backgrounds showed that 9 (34.6\%) patients were unemployed. Patients with HIV/AIDS in the course of their illness will experience opportunistic infections affecting the quality of life, one of which is their jobs. ${ }^{12}$

OC patients with HIV/AIDS, in this study, had more than one chief complaint. The most common complaint is white patches in the oral cavity 25 (96.2). White patches in the oral cavity are found in the pseudomembranous type of $\mathrm{OC}$ and plaque hyperplastic type, which is the most common type of OC. ${ }^{15}$ Recurrence in OC can occur in those who have low immune status and/or do not receive appropriate and adequate antifungal therapy. This study showed that 10 subjects $(38.5 \%)$ had recurring OC, while 16 $(61.5 \%)$ subjects only had it once. This finding is supported by a study conducted by Reza in Malang in 2014 , which showed that $79 \%$ of the subjects had OC for the first time. ${ }^{12}$

Candida species resistance in OC can occur secondarily from the inappropriate use of antifungals, and this is most commonly found in systemic antifungals. ${ }^{11} 5$ patients (19.2\%) were known to have systemic antifungal treatment; 10 patients (38.5\%) received topical antifungals and no history of systemic antifungal treatment found in the rest patients. Several patients also have difficulty recalling their previous treatments. This was influenced by various factors, especially their level of education. ${ }^{16}$

The most common mode of HIV transmission was heterosexual intercourse as many as 16 subjects (61.5\%), possibility by homosexual transmission with 7 subjects (26.9\%). This study also found 2 people with two HIV transmission modes, which were heterosexual intercourse and Injection Drug Users (IDUs). 9 HIV/AIDS patients have been suffering from the disease for more than one year, as found in $12(46.2 \%)$ people, while 9 people $(34.6 \%)$ have suffered from HIV infection for one to 3 years. The survival rate of HIV patients depends on the patient's immunity status and viral load. HIV-infected persons may find themselves asymptomatic until the occurrence of opportunistic infections, one of which is OC, due to weaker immune. ${ }^{6}$

WHO classifies HIV clinical stage into four stages based on several clinical symptoms related to HIV infection. OC can be found in patients in clinical stage II to clinical stage IV with at various severity. In clinical stage IV, severe OC affecting the esophagus, larynx, and trachea can be found. ${ }^{6}$ Most of the research subjects in this study were classified into clinical-stage group III as many as $14(53.8 \%)$ people. The absolute CD4 cell count of HIV/AIDS patients is an important parameter for the course of HIV/AIDS. OC can be found in an HIV-infected patient with an absolute CD4 cell count of $200-500$ cells $/ \mathrm{uL}$. Furthermore, a severe and recurrent $\mathrm{OC}$ can be found in patients with an absolute CD4 cell count $<200$ cells/uL. ${ }^{6}$ This study revealed that sixteen patients $(61.5 \%)$ had CD4 counts of $<200$ cells $/ \mu \mathrm{L}$. This data is supported by a 2015 study by Kumar in India that showed $71.4 \%$ of patients with a CD4 cell count $<200$ cells $/ \mu \mathrm{L}$ had fungal growth of Candida sp. from oral candidiasis lesions. ${ }^{17}$

As many as $21(80.8 \%)$ HIV/AIDS patients in this study had treated therapy, while $5(19.2 \%)$ patients had not yet received but were planned to receive antiretroviral therapy (ARV). ARV has been reported to decrease the incidence of opportunistic infections successfully. OC is a disease associated with HIV. Although patients are on ARV therapy, another factor such as the changes of virulence spectrum makes Candida sp. no longer the main cause of recurring case and complexity the treatment of OC. Research by Moges in Ethiopia in 2013 showed that OC was mostly found in patients who were not on ARV therapy $(58.7 \%)$. However, it was found in $41.3 \%$ of OC patients under ARV therapy. ${ }^{4}$

The identification of Candida sp. using mouth scrapings of 26 OC patients with HIV/AIDS resulted in 50 isolates of Candida $s p$. variants. Candida albicans was found in 22 (44\%) isolates, whereas non-albicans Candida sp. was found in $28(56 \%)$ isolates. This proves that there has been a change in the spectrum of causative species in OC with HIV/AIDS. ${ }^{4}$ Research in India by Dar in 2015 comparing Candida $s p$. in HIVseropositive patients and HIV-seronegative patients showed that colonies of Candida albicans species in 
HIV-seropositive were lesser than the HIVseronegative. Candida $s p$. that are rarely found in immunocompetent patients were also found in HIVseropositive patients, namely Candida dubliniensis, Candida glabrata, and Candida guilermondii. ${ }^{18} \mathrm{~A}$ meta-analysis study conducted in Sub-Saharan Africa in 2005 - 2015 showed a prevalence of non-albicans Candida species as much as $33.5 \%$ dominated with Candida glabrata, Candida krusei, and Candida tropicalis. The high prevalence of Candida krusei and Candida glabrata in HIV-infected populations in SubSaharan Africa has become a public health concern because this species is associated with fluconazole resistance. $^{19}$

An increasing number of non-albicans Candida colony isolates in the oral cavity HIV/AIDS patients is a public health concern as it is often associated with azole group antifungal resistance, that difficult to treat. Previous treatment may increase non-albicans Candida species colonies in HIV-infected individuals, especially antibiotics and antifungal therapy because it can affect the fungal colonization in the oral cavity. The broad-spectrum antibiotics are able to change the normal bacterial flora by killing bacteria and increasing the proliferation of Candida species. A study conducted by Mushi in 2016 in Tanzania suggested that prior antibiotic use was a statistically significant factor in increasing the colonization of non-albicans Candida species. $^{20}$

The pattern of resistance of Candida $s p$. was 3 $(6 \%)$ isolates resistant to ketoconazole, none of the isolates were resistant to nystatin, and $23(46 \%)$ isolates were resistant to fluconazole. The higher rate of fluconazole resistance of Candida sp., mainly nonalbicans Candida, is in line with research and literature. ${ }^{4,12,13}$

Nystatin has sensitivity up to $98 \%$, and it is still the drug of choice for the treatment of mild OC. The results of this study are in line with the findings of Moges of Ethiopia in 2013 that $96.8 \%$ of Candida isolates were still sensitive to nystatin. ${ }^{4}$ Meanwhile, the study by Dar in India in 2015 showed that only $61.1 \%$ isolates were sensitive, $36.1 \%$ moderate, and $2.8 \%$ resistant to nystatin. ${ }^{19}$ In general, the nystatin intrinsic and extrinsic resistance of Candida species is sporadic. The polyene (nystatin) resistance caused by change of sterol composition, which then decreases the polyene affinity to the plasma membrane. However, the highly resistant strain of Aspergillus terreus turned out to have ergosterol as the main sterol in its plasma membrane. This suggests that resistance to polyene is not always associated with changes in sterol composition, making mechanism of resistance to nystatin is not fully known. ${ }^{21}$ The nature of nystatin, which is non-soluble in water and non-absorbable through the intact skin, digestive tract, or vagina, is also one of the causative factors of such resistance. ${ }^{6}$

The difference between ketoconazole and fluconazole resistance in some Candida $s p$., although both are from the same azole drug group, was also reported in a study by Khan in India in 2015. In this study, Candida krusei species, which are primarily resistant to fluconazole, were found to be still sensitive to ketoconazole. Meanwhile, increased primary resistance to fluconazole was found in Candida glabrata. However, in Khan's study, no Candida glabrata resistance observed. On the other hand, it was found that none of the Candida tropicalis, which is the second-largest type of Candida after Candida albicans, was resistant to both azole drugs. ${ }^{22}$ The Moges' study, which was conducted in Ethiopia in 2013, reported diverse resistance figures, $6.6 \%$ Candida albicans were resistant to fluconazole, and $5.7 \%$ resistant to ketoconazole. Different results were also reported on non-albicans Candida where $16.6 \%$ of Candida glabrata were resistant to fluconazole and $12.5 \%$ resistant to ketoconazole, $35.3 \%$ of Candida tropicalis were resistant to fluconazole and $17.6 \%$ resistant to ketoconazole, $50 \%$ of Candida krusei were resistant to fluconazole, and none was resistant to ketoconazole. ${ }^{4}$ This study, however, only takes one sample from each patient. Ideally, to find out and evaluate the type of pattern and resistance, sample collection should be done repeatedly. ${ }^{22}$

Variation of the resistance rates of each Candida species to each antifungal drug proves that the factors that play a role include the host, drug, and pathogenic factors of the fungus itself. The different resistance mechanisms of each Candida sp. (fungal pathogenic factor) are the factors that mostly influence the antifungal resistance, especially the azole group, which has several mechanisms of resistance. Each species can play a role in different cellular target points. For example, Candida krusei, in particular, has a low affinity of the Ergosterol biosynthesis 11 (ERG11) gene naturally (intrinsically) so that the fluconazole drug cannot bind to the ERG11 protein; Candida glabrata can absorb exogenous sterols that changes the composition of fungal cell membrane sterols, which are not recognized by the azole antifungal; Candida albicans and Candida tropicalis can inactivate the Ergosterol biosynthesis 3 (ERG3) gene, changing the composition of the fungal membrane sterols, and both species are also able to increase the expression of the ERG11 gene, preventing the azole agent from binding. The difference between resistant azole antifungals (fluconazole and other azole groups) is the efflux pump process in fluconazole, involving different specific 
protein genes compared to other azole groups. Particularly to fluconazole, multiple drug resistance (MDR) gene expression causes an efflux pump process. An excessive expression is not effective as the drug will be removed from fungal cells even before the drug works. As for other azole groups, the Candida drug resistance (CDR) gene plays a role in the efflux pump process. The above mentioned can cause various resistant Candida species to antifungal agents. ${ }^{6,22}$

\section{REFERENCES}

1. Das P, Horton R. The cultural challenge of HIV/AIDS. Lancet 2013; 380: 309-10.

2. Direktorat Jendral Pengendalian Penyakit dan Penyehatan Lingkungan Kementerian Kesehatan. Situasi penyakit HIV \& AIDS di Indonesia. Jakarta: Ditjen PP \& PL Kementerian Kesehatan RI; 2016. Available

from: http://www.pusdatin.kemenkes.go.id/ (Accessed: 6 September 2017)

3. Maheshwari M, Kaur R, Chadha S. Candida species prevalence profile in HIV seropositive patients from a major tertiary care hospital in New Delhi, India. J Pathog 2016: 1-8.

4. Moges B, Bitew A, Shewaamare A. Spectrum and the in vitro antifungal susceptibility pattern of yeast isolates in Ethiopian HIV patients with oropharyngeal candidiasis. Int J Micro 2016: 1-8.

5. Dewi ISL, Hidayati AN. Manifestasi kelainan kulit pada pasien HIV dan AIDS. BIKKK 2015; 27(2): 97-105.

6. Kundu RV, Garg A. Yeast Infection: Tinea (Pityriasis) Versicolor, Malassezia (Pityrosporum) Folliculitis. In: Goldsmith LA, Katz SI, Gilchrest BA, Paller AS, Leffell D, Wolff K, editors. Fitzpatrick's Dermatology in General Medicine. $8^{\text {th }}$ ed. New York: McGraw-Hill; 2012. p. 2298-311.

7. Nadeem SG, Hakim ST, Kazmi SU. Use of CHROMagar Candida for the presumptive identification of Candida species directly from clinical specimens in resource-limited settings. Libyan J Med 2010; 5:2144-50.

8. Sariguzel FM, Berk E, Koc An, Sav H, Aydemir G. Evaluantion of CHROMagar Candida, Vitek 2 YST and Vitek MS for identification of Candida strains isolated from blood cultures. Infez Med 2015; 23(4): 318-22.

9. Kaur R, Dhakad MS, Goyal R, Haque A, Mukhopadhyay G. Identification and antifungal susceptibility testing of Candida species: a comparison of Vitek-2 system with conventional and molecular methods. J Glob Infect Dis 2016; 8(4): 139-46.

10. Suyoso S, Ervianti E, Barakbah J. Kandidiasis mukosa. Dalam: Suyoso S, Ervianti E, Barakbah J, editors. Panduan Praktik Klinis SMF Ilmu Kesehatan Kulit dan Kelamin RSUD Dr. Soetomo, Surabaya 2014. h. 95-7.

11. Saraswati A, Adiguna MS. Resistensi antijamur dan strategi untuk mengatasi. MDVI 2013; 40(2): 89-95.

12. Reza NR, Sugiman T, Basuki S. Uji kepekaan in vitro flukonazol terhadap spesies Candida penyebab kandidiasis oral pada pasien HIV/AIDS dengan Vitek II. BIKKK 2017; 29(3): 234-42.

13. Nelwan EJ, Indrasanti E, Sinto R, Nurchaida F, Sosrosumihardjo R. Antifungal susceptibility testing in HIV/AIDS patients: a comparison between automated machine and manual method. Acta Med Indones-Indones J Intern Med 2016; 48(1): 35-40.

14. Pfaller MA. Antifungal susceptibility testing. Waltham, MA: UpToDate Inc; 2017. Available from: http://www.uptodate.com (Accessed on December 02, 2017.)

15. Suyoso S. Kandidiasis Mukosa. Dalam: Bramono K, Suyoso S, Indriatmi W, Ramali LM, Widaty S, Ervianti E, editors. Dermatomikosis superfisialis pedoman dokter dan mahasiswa kedokteran. Edisi ke-2. Jakarta: Badan Penerbit Fakultas Kedokteran Universitas Indonesia; 2013. h: 120-48.

16. Yowel, Waluyo A, Kuntarti K. Umur Orang Dengan HIV AIDS (ODHA) Berhubungan Dengan Tindakan Pencegahan Penularan HIV. J Keperawatan Indones 2016; 19(3): 200-7.

17. Khan L, Kumar D, Muralidhar S, Banerjee U, Basir S, Mathur P. Diversity and antifungal resistance patterns of prevalent opportunistic pathogenic yeasts colonizing the oral cavities of asymptomatic Human Immunodeficiency Virus-infected individuals, and their relation to CD4 + counts. Indian J Sex Transm Dis AIDS 2015; 36(1): 53-8.

18. Dar MS, Sreedar G, Shukla A, Gupta P, Rehan AD, George J. An in vitro study of antifungal drug susceptibility of Candida species isolated from human immunodeficiency virus seropositive and Human Immunodeficiency Virus seronegative individuals in Lucknow population Uttar Pradesh. J Oral Maxillofac Pathol 2015; 19(2): 205-11

19. Mushi MF, Bader O, Taverne-Ghadwal L, Bii C, Groß U, Mshana SE. Oral candidiasis among African Human Immunodeficiency Virus-infected individuals: 10 years of systematic review and meta-analysis from sub-Saharan Africa. J Oral Microbiol 2017; 9(1): 1317579.

20. Mushi MF, Mtemisika CI, Bader O, Bii C, Mirambo MM, Groß U, et al. High oral carriage of Non-albicans Candida spp. among HIV-infected 
individuals. Int J Infect Dis 2016; 49: 185-8.

21. Canuto MM, Rodero FG. Antifungal drug resistance to azoles and polyenes. Lancet Infect Dis 2002; 2(September): 550-63.

22. Whaley SG, Berkow EL, Rybak JM, Nishimoto AT, Barker KS, Rogers PD, et al. Azole antifungal resistance in Candida albicans and emerging nonalbicans Candida species. Front Microbiol 2017; 7(January): 1-12. 